Irina M. Sakhno

Ph.D. in philology

Professor of the department of the theory and history of culture, liberal arts and humanities branch of the faculty of humanitarian and social sciences the Peoples' Friendship University of Moscow. e-mail:drsachno@msn.com

Russia, Moscow

ORCID 0000-0002-5510-6684

ResearcherID: B-2047-2016

Scopus Author ID: 57196349789

DOI: $10.36340 / 2071-6818-2020-16-1-38-55$

\title{
Alexander Burganov's Alternative Worlds and Visual Ideograms
}

Summary: The creative work of famous Russian sculptor Alexander Nikolayevich Burganov in the context of a system of copyright signs and conventional symbols, the artist's relationship with the world and himself from the standpoint of symbolic valency which combines two forms of sculptural expressiveness - figurative and abstract art, are analyzed in the article. Considering hidden comparisons in Burganov's work, the author analyzes the mythological and metaphorical thinking of the artist who appeals to invariable ancient images and surreal poetics that ultimately form an organic constellation of images and their harmonious completeness.

Alexander Burganov's sculptures are a productive space for an ambivalent play of many meanings and visual tautologies. The artist's original reflections involve visual patterns that the sculptor articulates in his works: tradition and antiquity, cultural memory and modern philosophical contexts, semiotics of drapery/folds, a cage as a special sign, a symbol.

The sculptor's image paradigm also develops at the intersection of visual and verbal contexts, although the word as such is absent; however, the narrative discourse is obvious.

The use of diverse semantics of sculpture-gestures plays an important role. Alexander Burganov's sculptures, establishing a movable border between tradition and the historical avant-garde, reduce and reproduce new cultural meanings. Overcoming the boundaries of artistic optics and recreating new polystylism, he models a special lightness of sculpture and mobility of images in his sculptural works.

The author draws attention to the sculptor's ability to combine the most diverse layers of culture thus translating the artist's original semantics based on allusions and allegories giving the viewer the right to independently navigate through the mazes of visual memory. The author emphasizes that the dialogue between the artist and the audience through symbolically abstract signs begins to model new forms of artistic matter and affect the human ordering of the world.

Burganov's artistic practice recreates the space of another reality - the world behind the looking glass of everyday life. The sculptor's alchemy is such that the viewer immerses into 
the space of spiritual worlds, comprehends the sculptural plasticity and its expressiveness using the language of allegories and symbols. The observer establishes the inner essence of things, hidden conceptual impulses, tries to discover the spiritual in the material.

Keywords: Alexander Burganov, modernism, archaic, cultural memory, drapery/ fold, cage, hand.

Reflecting on the legacy of famous Russian sculptor Alexander Nikolayevich Burganov, one understands that it is impossible to be locked up in the space of a single field of interpretation due to the fact that we have a new visualization that combines tradition and "intellectual abstraction" ". Let's try to trace these difficult dynamics of the artist's relationship with the world and with himself relying on optics of symbolic valency in which two forms of sculptural expressiveness, figurative and abstract art, are combined. In the essay "Waking Dreams", Arthur Danto, the famous American philosopher and art critic, remarkably defined the essence of all creativity: "Works of art are embodied meanings" 2 regardless of what the viewer sees: either figurative painting or Andy Warhol's brillo soup boxes. The viewer's task is to interpret the signs and meanings that the artist presents with the help of visual language. The discovery of hidden contexts in Burganov's sculptures is not an easy task owing to the fact that its visibility is based on the representation of not only the external and internal space but also on the system of copyright signs and conventional symbols. This mosaic of hidden comparisons is based on the artist's mythological and metaphorical thinking, an appeal to invariable antique images and the magic of surrealistic poetics which ultimately forms an organic constellation of images and their harmonious completeness. Burganov's sculptures are a productive space for an ambivalent play of many meanings and visual tautologies. He recreates the personal by restoring the cultural memory, reducing new contexts of individual existence, establishing a mobile connection between the classical tradition and the historical avant-garde ${ }^{3}$. His artistic optics are synthetic, and the polystylism is sensory which gives reason to consider creative practice in the context of an articulated artistic statement on the secrets of the human soul and the subconscious, on the drama of life itself: "My sculptures are tragic and encoded," commented Burganov on his work, "I understand the tragic essence of everything that happens: it is still very far from good, and it is unclear whether the good will ever rule" 4

Combining completely different layers of culture, the sculptor transmits his own semantics based on allusions and allegories, giving the viewer the right to flow through

1. Clark K. Nudity in Art. Study of the Ideal Form / Transl. by M. V. Kurenna and others. St. Petersburg: ABC Classic, 2004. P. 337.

2. Danto A. Waking Dreams // Danto A. What is Art? Moscow: Ad Marginem Press, 2018. P. 48.

3. In our opinion, Alexander Burganov's ideostyle can not be reduced only to magical realism and surrealism due to the fact that his artistic practice is much wider than the established labels.

4. Watchel C. "Surrealism in Sculpture. Alexander Burganov." Artifex.ru Almanac. Web resource. URL: https://artifex.ru/\%D1\%81\%D0\%BA\%D1\%83\%D0\%BB $\%$ D $1 \% 8 \mathrm{C} \% \mathrm{D} 0 \% \mathrm{BF} \% \mathrm{D} 1 \% 82 \% \mathrm{D} 1$ $\% 83 \% \mathrm{D} 1 \% 80 \% \mathrm{D} 0 \% \mathrm{~B} 0 / \% \mathrm{D} 0 \% \mathrm{~B} 0 \% \mathrm{D} 0 \% \mathrm{BB} \% \mathrm{D} 0 \% \mathrm{~B} 5 \% \mathrm{D} 0 \% \mathrm{BA} \% \mathrm{D} 1 \% 81 \% \mathrm{D} 0 \% \mathrm{~B} 0 \% \mathrm{D} 0 \% \mathrm{BD} \%$ D0\%B4\%D1\%80-\%D0\%B1\%D1\%83\%D1\%80\%D0\%B3\%D0\%B0\%D0\%BD\%D0\%BE\%D0\%B2 (date of referral 07.02.2020) 


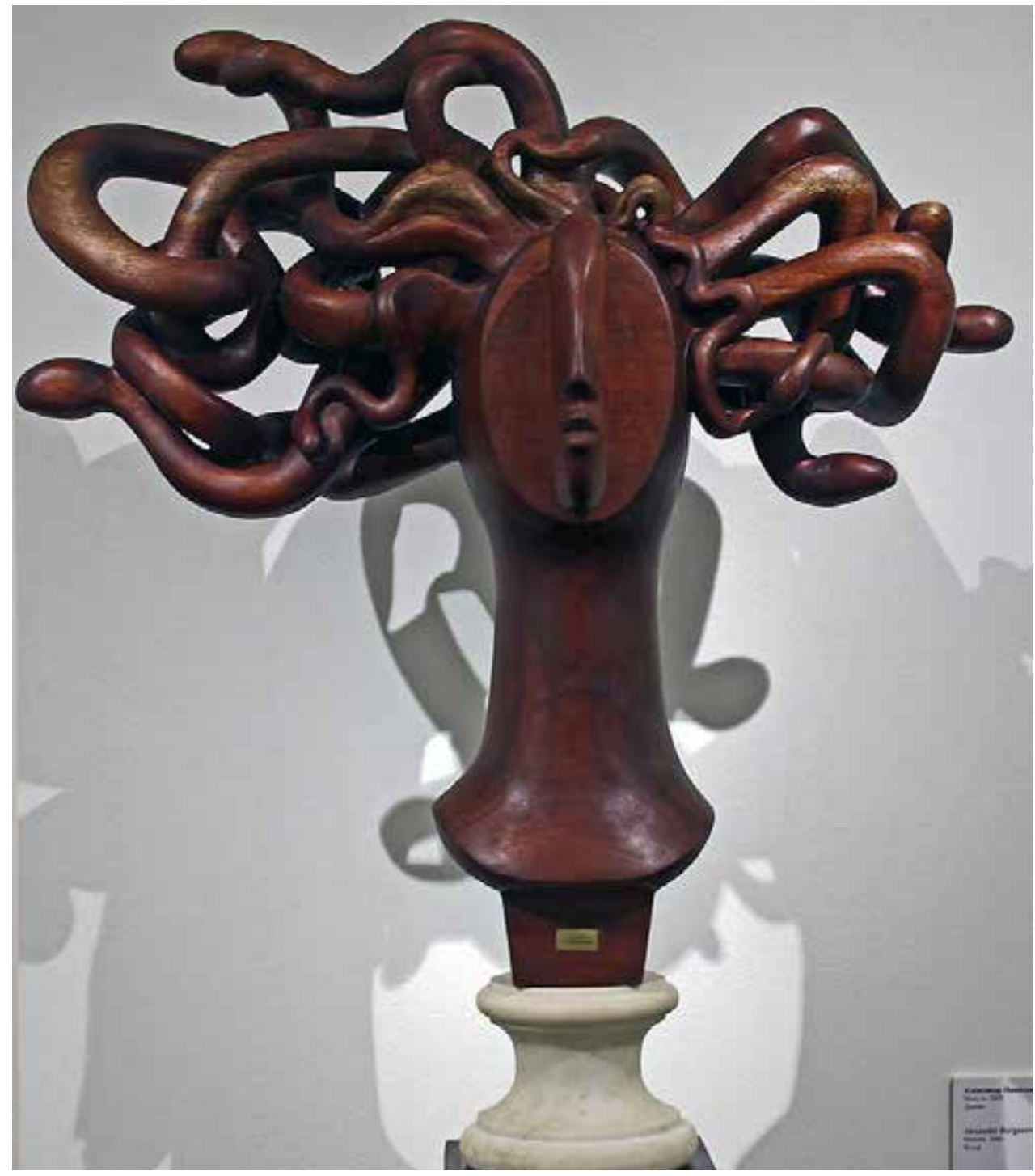

Alexander Burganov. Medusa. 2008. Wood

the mazes of visual memory. In his works, we find an undoubted reference to ancient mythology and ancient Cycladic idols - marble and obsidian sculptures of the Cyclades (an archipelago in the southern Aegean Sea) created between 3500 and 2000 BC. If one compares the Medusa sculpture made of wood (2000) to the Cycladic canonical figures $^{5}$, a similarity of sculptural symbols can be noticed in the restrained sophistication of simple lines and minimalist geometry.

5. Marble Idols of the Plastiras Phase. Archaeological Museum, Munich // Image Source: Cyclades Art. Web resource. URL: https://donsmaps.com/cyclades.html (date of referral 07.02.2020). 


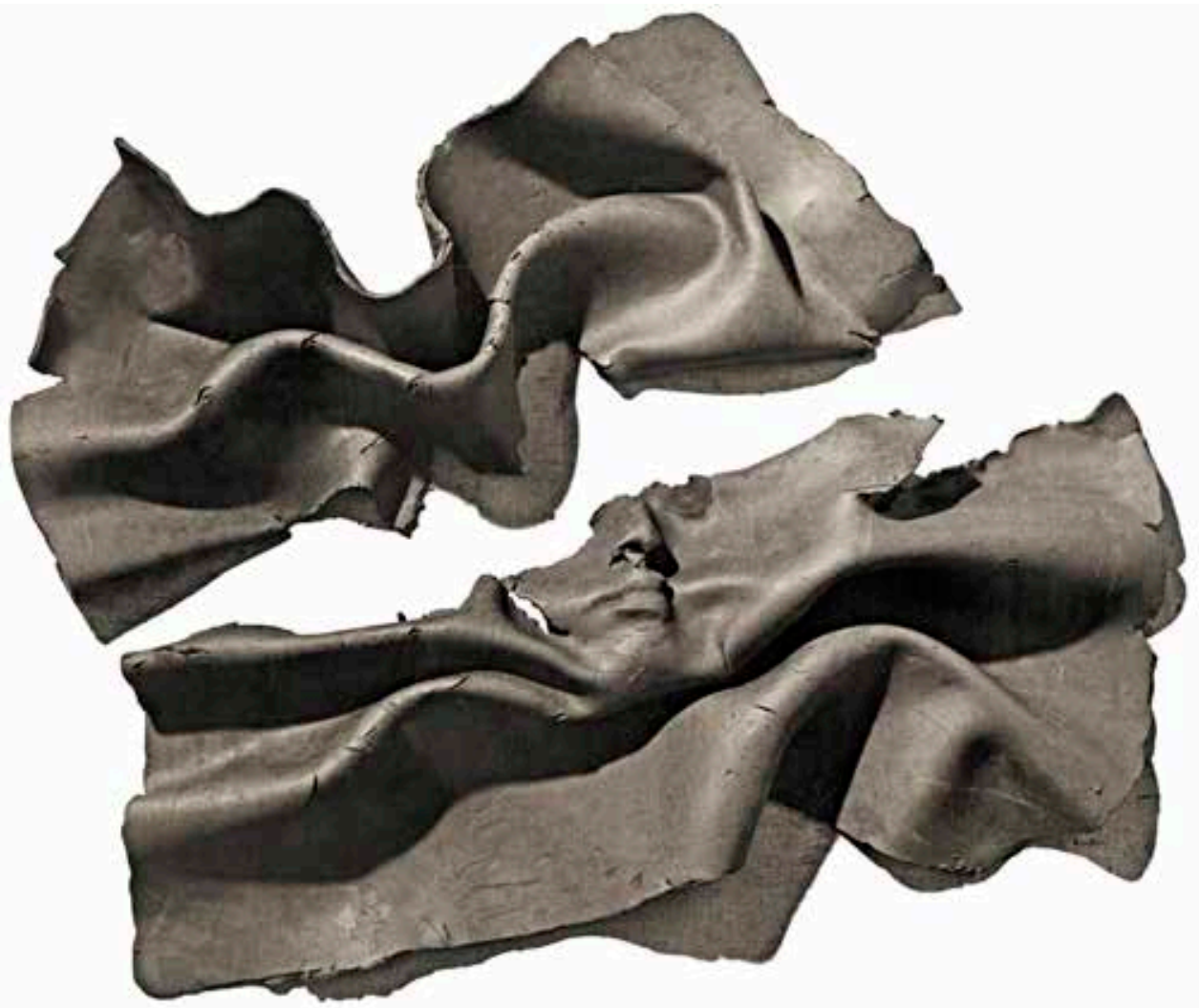

Alexander Burganov. Self-portrait in the Wind. 1987. Bronze. $90 \times 90 \times 20$

These figures, created much earlier than the Greek Kouros and Kore, anthropomorphic in essence, without eyes and lips, with a very specific straight nose, inspired many modernist artists: Amadeo Modigliani, Pablo Picasso, Constantine Brancusi, Hans Arp, Giorgio de Chirico, and others. Burganov, appealing to ancient Greek antiquity and the myth of Medusa Gorgon, restores archaic cultural layers and at the same time demonstrates modern materials and techniques, turning this sculpture into a capacious symbol of the victory of life over death - it is no accident, after all, Gorgon's blood was used by Asclepius to heal people.

An angel and angel wings are other recurring visual ideograms in the sculptor's work: Annunciation (1987), An Angel (2006), A Prophet. Dedication to Chagall (2017), A Girl and an Angel (2005), An Angel of Peace (2015), The Angels composition - bas-reliefs for the sculptural decoration of the Cathedral of Christ the Savior in Moscow ${ }^{6}$, as well as numerous fluttering draperies stylistically resembling wings of an angel. Appealing to the early Christian tradition of depicting angels as messengers of God's word

6. Alexander Burganov's exhibition with the same name "White Angel" was held in the museum complex "Horse Yard" at the Sergiev Posad Historical and Art Museum-Reserve on July 6, 2016. 


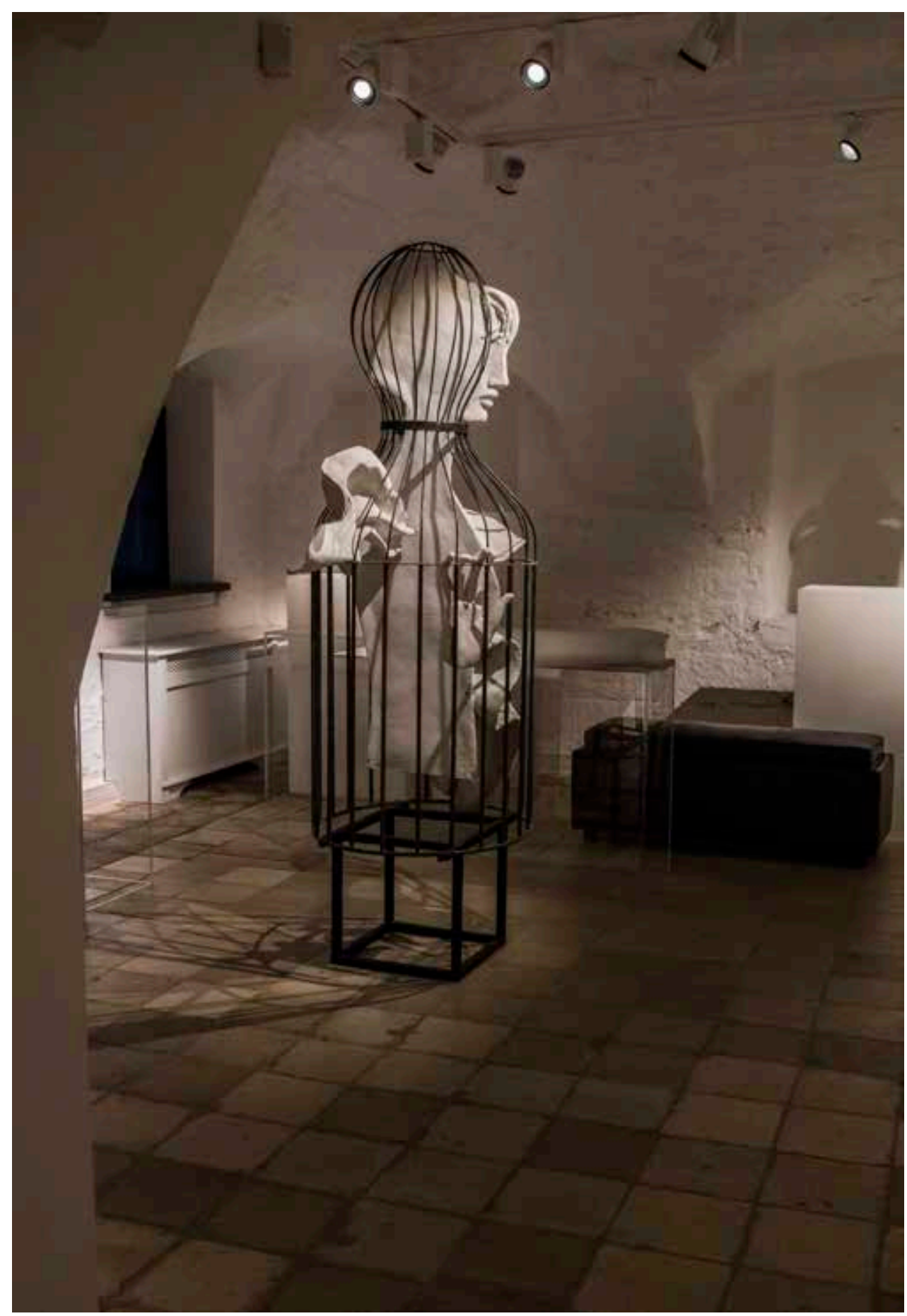

Alexander Burganov. The Cage. Metal, gypsum, plastic. 1995 
with large wings ${ }^{7}$, the sculptor uses other tools to visually capture the divine presence. Angels are messengers of another reality, an element of a different perception of time, part of universal metamorphoses and witnesses of the transformation of the human soul. The sculptor's original draperies created in stone and bronze perform a similar function. They illustrate an interesting philosophical metaphor that marks the noumenal and spiritual space of a person. In this sense, the sculptor is close to the post-modern interpretation of the cultural model of "drapery/folds", represented by modern thinkers (Maurice Merleau-Ponty, Martin Heidegger, Gilles Deleuze, Michel Foucault, Carmen Vidal, and others) in the context of the most important visual and philosophical pattern in the history of art.

Gilles Deleuze, reflecting on Leibniz's phenomenon of a Monad, compared his philosophical revelations with baroque architecture aimed at universal infinity: "The main feature of baroque," Deleuze comments, "is a fold directed towards infinity. And above all, baroque differentiates them according to two directions, two infinities, as if infinity had two floors: folds of matter and folds in the soul ${ }^{8}$." This bipolarity (matter below, the soul above, elevated and low, upper and lower floors of the cosmic house) and micro/macro perceptions as representatives of the world take, according to the philosopher, different forms in the shape of draperies and folds meaning the internal energy of the world filled with monads and living souls. Such an understanding of the world, according to Deleuze, is characteristic of Italian mannerism of the second half of the $16^{\text {th }}$ century when Cosmos was understood as plastic matter with changes, waves, and folds. Another important formulation of Deleuze, in our opinion, is the establishment of a connection between such constants as a fold, time and memory in the "Foucault" essay. Emphasizing the close connection of such strata of being as the past and present, the philosopher actualizes Foucault's idea of the presence of the internal in the external by smoothing the folds of being and defining time as absolute memory. According to Merleau-Ponty, a fold is "patterned interlacings" or "intermediate states" whereas according to Foucault it is "interweaving" and "intersection" in accordance with the Platonic model of "weaving": "This interweaving resembles a fight, a battle between two irreconcilable opponents between the two forms of being-knowledge. To put it another way, this is also intentionality but of the opposite effect and pulled apart in two directions: it becomes vanishingly small or microscopic. It's not even a fold of being but

7. "An image of an angel originated in the East, played a significant role in Greece and even more in pagan Rome. At first, the new religion turned its back on it, finding no correspondences for it in either the Old or New Testaments; however, the image possessed such strength that it overcame all obstacles and has subordinated the Christian consciousness to the present day. Only such an independent mind as Rembrandt's could sometimes allow himself to break away from tradition and turn to the spirit of the Bible and to the worldview that prevailed in Christian art during that short period when the pagan image of Victory was in decline and had not yet been reborn into the Christian guise of the messenger of God "// Saxl F.

8. Deleuze J. A Fold. Leibniz and Baroque. Moscow: Logos, 1998. P. 7 
the interweaving of its two forms." ${ }^{9}$ The external as an emotional experience of the internal, a fold as a thought process and a property of matter, folds of the soul and its self-development are the metaphysical designation of a fold which, according to Spanish researcher Carmen Vidal, defines the symbolism of the material and spiritual space of the $80 \mathrm{~s}$ of the $20^{\text {th }}$ century and its baroque character ${ }^{10}$. In this context, it seems logical to us to consider Burganov's draperies as a kind of folding, split, and transformation, as a kind of sensual fold line and a transfer to foreign reality modeling the special lightness of plasticity and the mobility of the images of his sculptural works.

In the works A Cage (1988), A Cage (2015), A Scream (2000), Monument to the Marquis de Sade (1987), Soul (1997), Venus of Space (2015), a birdcage, symbolizing the lack of person's freedom and his or her soul, appears. Marking the situation of social restrictions, taboos, and suppression of the personal principle, this connotation is very important for the sculptor. Alexander Burganov commented on this symbol: "Yes, a cage is a cage. It is an integral part of our life. It would be untrue not to notice it. For me, this is also the shell of the body, inside which a soul that does not have a subject sign is enclosed. A cage is an object from which one flies out or remains within forever. And therefore, as the formula of our being, it is an integral part of our alphabet for designating life. Its rods make a wonderful visual contrast in the hands of the sculptor in order to explain this world." 11

We can definitely say that Burganov presents a personal story using the plastic possibilities of sculpture. The dialogue between the artist and the public through symbolically abstract signs begins to model new forms of artistic matter and affect the human ordering of the world. Burganov's artistic practice recreates the space of another reality - the world behind the looking glass of everyday life. The sculptor's alchemy is such that the viewer immerses into the space of the spiritual worlds, comprehends the sculptural plasticity and its expressiveness using the language of allegories and symbols. The observer establishes the inner essence of things, hidden conceptual impulses, tries to discover the spiritual in the material. Vasily Kandinsky's installation on the synaesthetic vision and comprehension of the internal properties of objects and forms living in the mental plane is undoubtedly close to the artist of the sculpture $A$ Cage: "The world resonates. It is the Cosmos of spiritually acting beings. Such is the dead matter of the living Spirit ${ }^{12}$," Kandinsky wrote in the article "On the Question of Form". Burganov not only reinterprets the nature of the Universe and the laws of human existence but also, appealing to emblematic iconography, makes the secret visible.

9. Deleuze J. Foucault. Moscow: Humanitarian Literature Publishing house, 1998. Web resource. URL: https://royallib.com/book/delyoz_gil/fuko.html (date of referral 08.02.2019)

10. See more: Vidal M. K. "The Death of Politics and Sex in the Show of the Eighties" // New Literary History. V. 24, No. 1. Charlottesville, 1993. Pp.183-185.

11. Burganov A. N. "A Smile of the Blind. An Interview of the Artist with Himself" // Burganov House. The Space of Culture. 2010. No. 2. P. 56.

12. Kandinsky V. "On the Question of Form" // Kandinsky V. Selected Works on the Theory of Art. V. 1. Moscow: Gilea, 2001. P. 225. 


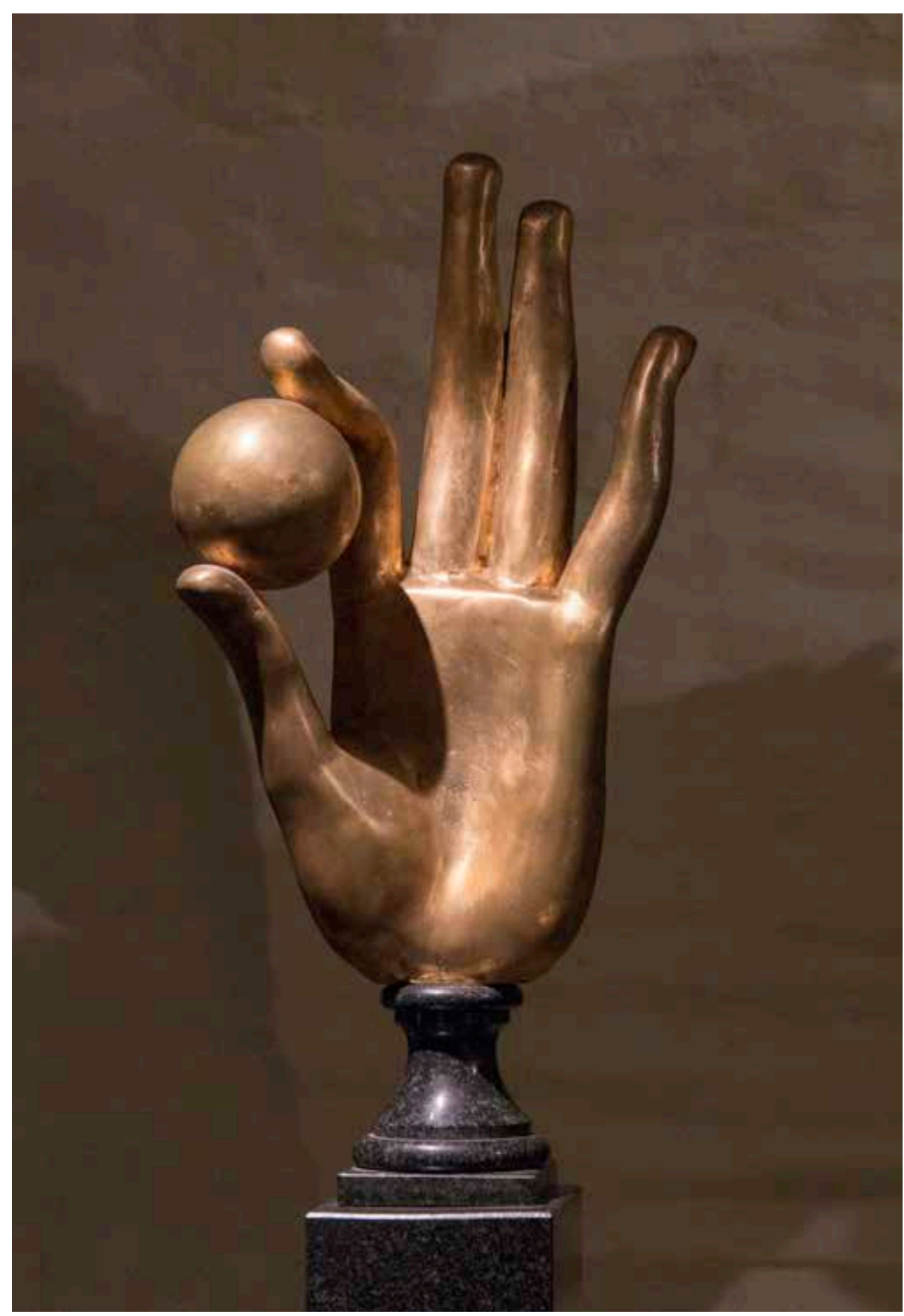

Alexander Burganov. The Hand of the Creator. 2010. Bronze 
Sculpture-gestures occupy the most important place in Alexander Burganov's creative legacy. The artist attaches great importance to them since the language of non-verbal semiotics has played a significant role in the interpretation of the system of imagery (iconography) and hidden meanings (iconology) of the picture from ancient times. Recently, the book Body language. Postures and Gestures in Art ${ }^{13}$ by famous researcher Morris Desmond, in which the author talks in a fascinating manner about kinetics in the masterpieces of world art, has been translated and published in Russia. Explaining the important signs of gestural articulation in art, the researcher establishes the canonical non-verbal patterns presented by artists throughout the history of fine art. For Burganov, the hand becomes the most important visual ideogram. Here is how he himself writes about it:

"The hand is the face of God.

The hand of God has neither individuality, nor psychology, nor resemblance to an individual.

This is not an image of a body fragment.

This is a sign of fate.

With an outstretched hand, God sees and listens to us.

God is God.

However, on the other hand, the hand is a symbol of us.

This is the face of our soul and our problems.

The hand of God and our hand are facing each other.

We are waiting for our fingers to meet.

We ask for salvation.

We ask to forgive us.

We ask to return the paradise and immortality, from which we were once expelled, to us.

This is our dream, our prayer, our hope.

Therefore, in short, the hands in my work are my prayers." 14

The hand of the Creator is an unalterable sign-symbol which the sculptor repeats in different variations. He passionately handles this artistic medium and offers the audience different forms of decoding it: a prayer gesture, a cry gesture, a gesture indicating and blessing, showing an upward movement, etc. These artifacts are designed to enhance the observer's empathy and, based on the traces left, reconstruct the mechanisms of visual stimuli.

The rhetorical message or hidden verbal subtext is an important feature of these sculptural compositions. The sculptor's paradigm of the image develops at the intersection of visual and verbal contexts, although the word as such is absent; however, the narrative discourse is obvious. Burganov's images are saturated with metaphysical and didactic rhetoric, linguistic codes and a special form of the meaning creation when

13. Desmond M. Body Language. Postures and Gestures in Art. Moscow: Ad Marginem, 2019.

14. The Image of a Hand in Alexander Nikolaevich Burganov's Work. Web resource. URL: http:// burganov.ru/virtualnaja-vystavka/ (date of referral 08.02.2019) 
a representation of a mixed type is established, characteristic of the art of modernism. He focuses his attention on the frame ${ }^{15}$, inside which individual and general cultural meanings are formed. First of all, we mean the semantic framework and stable interpretation schemes which allow the sculptor to create a visual environment, extremely saturated with codes and conventional signs. Burganov offers the viewer a visual theater similitude in which an image as a sign-symbol and linguistic reality travels in space and time with an emphasis on the conceptual and internal complexity of the representation. The artist seeks to induce the viewer to unhurried and thoughtful reflection, to contemplate new anthropology of visuality and grammar of gestures in sculpture, in the continuum of which the boundaries between the subject and the object are easily overcome.

\section{REFERENCES}

1. Burganov A. N. 2010. "Ulybka slepykh (interv'yu khudozhnika s samim soboy)" ["A Smile of the Blind. An Interview of the Artist with Himself"], Nauchno-analiticheskiy zhurnal "Dom Burganova. Prostranstvo kul 'tury" [Art, Literature and Music Scientific and Analytical Journal "Burganov House. The space of culture"], no. 2. (in Russian)

2. Vidal, M.C. 1993. "The Death of Politics and Sex in the Eighties Show", New Literary History, no. 24(1), pp. 171-194. DOI:10.2307/469277 (in English)

3. Watchel, C. "Surrealism in Sculpture. Alexander Burganov.", Artifex.ru Almanac, vol.12. Available at: https://artifex.ru/\%D1\%81\%D0\%BA\%D1\%83\%D0\%BB\%D1\%8C\%D0\%B F\%D1\%82\%D1\%83\%D1\%80\%D0\%B0/\%D0\%B0\%D0\%BB\%D0\%B5\%D0\%BA\%D1 $\% 81 \% \mathrm{D} 0 \% \mathrm{~B} 0 \% \mathrm{D} 0 \% \mathrm{BD} \% \mathrm{D} 0 \% \mathrm{~B} 4 \% \mathrm{D} 1 \% 80-\% \mathrm{D} 0 \% \mathrm{~B} 1 \% \mathrm{D} 1 \% 83 \% \mathrm{D} 1 \% 80 \% \mathrm{D} 0 \% \mathrm{~B} 3$ $\% \mathrm{D} 0 \% \mathrm{~B} 0 \% \mathrm{D} 0 \% \mathrm{BD} \% \mathrm{D} 0 \% \mathrm{BE} \% \mathrm{D} 0 \% \mathrm{~B} 2$ (accessed: 01.03. 2020) (in Russian)

4. Danto, A. C. 2013. What is Art? (in English)

5. Deleuze, J. 1992. A Fold. Leibniz and Baroque. (in English)

6. Deleuze, J. 1998. Foucault. Moscow: Humanitarian Literature Publishing house, Available at: https://royallib.com/book/delyoz gil/fuko.html (accessed: 01.03. 2020)

7. Desmond, M. 2019. Postures: Body Language in Art, Thames \& Hudson. (in English)

8. Hvattum, M., 2019. Style: "Notes on the Transformation of a Concept", Architectural Histories, no. 7(1), p.22. DOI: http://doi.org/10.5334/ah.367 (in English)

9. Saxl, F. 2018. "Constants and Variations", World of Images. Images of the World. Anthology of visual culture research. (in Russian)

10. Kandinsky, V. 2001. "On the Question of Form", Kandinsky V. Selected Works on the Theory of Art. vol. 1. Moscow (in Russian)

11. Clark, K. 2004. Nudity in Art. Study of the Ideal Form / Transl. by M. V. Kurenna and others. (in Russian)

12. The Image of a Hand in Alexander Nikolaevich Burganov's Work. Available at: http://burganov. ru/virtualnaja-vystavka/ (accessed: 01.03. 2020) (in Russian)

13. Goffman E. 1974. Frame Analysis: An Essay on Organization of Experience. Cambridge (in English)

14. Cyclades Art. Available at: https://donsmaps.com/cyclades.html (accessed: 01.03. 2020) (in English)

15. Zuromskis, C. 2018. "The Social Lives of Archival Photographs," Archives of American Art Journal, vol. 57, no. 1, pp.76-85. DOI: https://doi.org/10.1086/698337 (in English)

16. Warner, E. S. 2017. "Marketing the Monumental: Wall Painting at Midcentury," Archives of American Art Journal, vol. 56, no. 2 pp. 26-49. DOI: https://doi.org/10.1086/695628 (in English)

15. See more: Goffman E. Frame Analysis: An Essay on Organization of Experience. Cambridge, 1974. 


\section{Ирина Михайловна Сахно доктор наук профессор кафедры теории и истории Российского университета дружбы народов e-mail:drsachno@msn.com Россия, Москва \\ ORCID 0000-0002-5510-6684 ResearcherID: B-2047-2016 Scopus Author ID: 57196349789}

DOI: $10.36340 / 2071-6818-2020-16-1-38-55$

\section{Альтернативные миры и визуальные идеограммы Александра Бурганова}

Аннотаичя: В статье анализируется творчество известного российского скульптора Александра Николаевича Бурганова в контексте системы авторских знаков и конвенциональных символов, взаимоотношение художника с миром и с собой, с позиций символической валентности, в которой сопряжены две формы пластической выразительности - фигуративное и абстрактное искусство. Рассматривая скрытые сопоставления в творчестве А. Н. Бурганова, автор анализирует мифологическое и метафорическое мышление художника, апеллирующего к устойчивым античным образам и сюрреалистической поэтике, что в конечном итоге образует органическую констелляцию образов и их гармоническую завершенность.

Скульптуры Александра Бурганова — это плодотворное пространство для амбивалентной игры множества смыслов и визуальных тавтологий Авторские рефлексии затрагивают визуальные паттерны, которые артикулирует скульптор в своих работах: традиция и архаика, культурная память и современные философские контексты, семиотика драпировки /складки, клетка как особый знак - символ.

Авторская парадигма образа развивается также на пересечении визуального и вербального контекстов, хотя слово как таковое отсутствует, но дискурс нарратива очевиден.

Важное место занимает обращение к разнообразной семантике скульптуржестов. Скульптуры Александра Бурганова, устанавливая подвижную границу между традицией и историческим авангардом, редуцируют и воспроизводят новые культурные смыслы. Преодолевая границы художественной оптики и воссоздавая новую полистилистику, он в своих скульптурных работах моделирует особую легкость пластики и подвижность образов.

Автор привлекает внимание к способности скульптора соединять самые разные пласты культуры, транслируя таким образом авторскую семантику, основанную на аллюзиях и иносказаниях, предоставляя зрителю право самостоятельно плыть по лабиринтам визуальной памяти. Автор подчёркивает, что диалог художника 
с публикой посредством символически-абстрактных знаков начинает моделировать новые формы художественной материи и влиять на человеческую упорядоченность мира.

Художественная практика Бурганова воссоздаёт пространство другой реальности - зазеркалья повседневного существования. Алхимия скульптора такова, что зритель погружается в пространство духовных миров, постигает скульптурную пластику и её выразительность с помощью языка иносказаний и символов. Наблюдатель устанавливает внутреннюю суть вещей, скрытые концептуальные импульсы, старается обнаружить духовное в материальном.

Ключевые слова: Александр Бурганов, модернизм, архаика, культурная память, драпировка/складка, клетка, рука.

Размышляя о наследии известного российского скульптора Александра Николаевича Бурганова, понимаешь, что невозможно замкнуться в пространстве единого поля интерпретации, потому что перед нами новая изобразительность, сочетающая традицию и «интеллектуальную абстракцию» ${ }^{1}$. Попробуем проследить эту непростую динамику взаимоотношений художника с миром и с собой, полагаясь на оптику символической валентности, в которой сопряжены две формы пластической выразительности - фигуративное и абстрактное искусство. Известный американский философ и художественный критик Артур Данто в эссе «Сны наяву» замечательно определил суть всякого творчества: «Произведения искусства - это и есть воплощённые смыслыл» ${ }^{2}$, независимо от того, что зритель видит: фигуративную живопись или коробки из-под супа Brillo Энди Уорхолла. Задача зрителя - интерпретировать знаки и те смыслы, которые художник репрезентирует с помощью визуального языка. Обнаружение скрытых контекстов в скульптурах Бурганова - задача непростая в силу того, что его визуальность основана на репрезентации не только внешнего и внутреннего пространства, но и на системе авторских знаков и конвенциональных символов. Эта мозаика скрытых сопоставлений опирается на мифологическое и метафорическое мышление художника, апелляцию к устойчивым античным образам и магию сюрреалистической поэтики, что в конечном итоге образует органическую констелляцию образов и их гармоническую завершённость. Скульптуры Бурганова - это плодотворное пространство для амбивалентной игры множества смыслов и визуальных тавтологий. Он воссоздаёт личное посредством реставрации культурной памяти, редуцирует новые контексты индивидуального существования, устанавливает подвижную связь между классической традицией и историческим авангардом ${ }^{3}$. Его художественная оптика синтетична, а полистилистика сенсорна, что даёт основание рассматривать творческую практику в контексте артикулированного художественного

1. К Кларк К. Нагота в искусстве. Исследование идеальной формы / Пер. М. В. Куренной и др.СПб.: Азбука-классика, 2004.- С. 337.

2. Данто А. Сны наяву // Данто А. Что такое искусство.- М.: Ад Маргинем Пресс, 2018. - С. 48.

3. На наш взгляд, нельзя сводить идиостиль Александра Бурганова только к магическому реализму и сюрреализму, потому что его художественная практика значительно шире устоявшейся маркировки. 
высказывания о тайнах человеческой души и подсознании, о драматизме самой жизни: «Мои скульптуры трагичны и зашифрованы, - комментировал Бурганов своё творчество,- я понимаю трагическую сущность всего происходящего: что до добра ещё очень далеко, и непонятно, будет ли оно когда-нибудь» ${ }^{4}$.

Соединяя самые разные пласты культуры, скульптор транслирует авторскую семантику, основанную на аллюзиях и иносказаниях, предоставляя право зрителю самостоятельно плыть по лабиринтам визуальной памяти. В его работах мы встречаем несомненную отсылку к античной мифологии и древним кикладским идолам мраморным и сделанным из обсидиана скульптурам Кикладских островов (архипелаг в южной части Эгейского моря), созданных в период между 3500 и 2000 годами до н.э. Если сравнить скульптуру «Медуза» 2000 года, выполненную из дерева, и кикладские канонические фигурины ${ }^{5}$, можно увидеть сходство пластических символов в сдержанной утончённости простых линий и минималистской геометрии.

Эти фигуры, созданные значительно раньше греческих куросов и кор, антропоморфные по своей сути, без глаз и губ, с очень специфическим прямым носом, вдохновляли многих художников модернистского толка: Амадео Модильяни, Пабло Пикассо, Константина Бранкузи, Ханса Арпа, Джорджо де Кирико и др. Бурганов, апеллируя к древнегреческой античности и мифе о Медузе Горгоне, реставрирует архаические культурные пласты и одновременно демонстрирует современные материалы и техники, превращая эту скульптуру в ёмкий символ победы жизни над смертью - не случайно ведь кровь Горгоны использовалась Асклепием в целях врачевания людей.

Ещё одна повторяющаяся визуальная идеограмма в творчестве скульптора ангел и ангельские крылья: «Благовещение» (1987), «Ангел» (2006), «Пророк. Посвящение Шагалу» (2017), «Девушка и ангел» (2005), «Ангел Мира» (2015), композиция «Ангелы» - барельефы для скульптурного убранства Кафедрального соборного храма Христа Спасителя в Москве ${ }^{6}$, а также многочисленные развевающиеся драпировки, стилистически напоминающие крылья ангела. Апеллируя к традиционной раннехристианской традиции изображения ангелов как вестников Божьего слова с большими крыльями ${ }^{7}$, скульптор использует иные инструменты

4. Вотчель К. Сюрреализм в скульптуре. Александр Бурганов // Альманах «Artifex.ru». Ceтевой ресурс. URL: https://artifex.ru/\%D1\%81\%D0\%BA\%D1\%83\%D0\%BB $\% \mathrm{D} 1 \% 8 \mathrm{C} \%$ D0\%BF\%D1\%82\%D1\%83\%D1\%80\%D0\%B0/\%D0\%B0\%D0\%BB $\%$ D0 $\%$ B5 $\%$ D0 $\%$ BA $\%$ D1\%81\%D0\%B0\%D0\%BD\%D0\%B4\%D1\%80-\%D0\%B1\%D1\%83\%D1\%80\%D0\%B3\%D$0 \% \mathrm{~B} 0 \% \mathrm{D} 0 \% \mathrm{BD} \% \mathrm{D} 0 \% \mathrm{BE} \% \mathrm{D} 0 \% \mathrm{~B} 2$ (дата обращения 7.02.2020).

5. Мраморные идолы фазы Пластирас. Археологический музей. Мюнхен // Источник изображения: Cyclades Art. Сетевой ресурс. URL: https://donsmaps.com/cyclades.html (дата обращения: 07.02.2020).

6. 6 июля 2016 года в музейном комплексе «Конный двор» Сергиево-Посадского историкохудожественного музея-заповедника прошла выставка Александра Бурганова под одноимённым названием «Белый ангел».

7. «Образ ангела возник на Востоке, сыграл немалую роль в Греции и ещё бо́льшую - в языческом Риме. Новая религия вначале отвернулась от него, не найдя для него соответствий ни в Ветхом, ни в Новом завете, но образ обладал такой силой, что преодолел все препят- 
визуальной фиксации Божественного присутствия. Ангелы - вестники другой реальности, элемент иного восприятия времени, часть вселенских метаморфоз и свидетели трансформации человеческой души. Аналогичную функцию выполняют авторские драпировки, созданные в камне и бронзе, которые иллюстрируют интересную философскую метафору, знаменующую ноуменальное и духовное пространство человека. В этом смысле скульптор близок к постмодернистской трактовке культурной модели «драпировки/складки», которая репрезентировалась современными мыслителями (Морис Мерло-Понти, Мартин Хайдеггер, Жиль Делёз, Мишель Фуко, Кармен Видаль и др.) в контексте важнейшего визуального и философского паттерна в истории искусства.

Жиль Делёз, размышляя о феномене монады Лейбница, сравнивал его философские откровения с архитектурой барокко, направленной к вселенской бесконечности: «Основная черта барокко,- комментирует Делёз,- направленная к бесконечности складка. И прежде всего барокко их дифференцирует соответственно двум направлениям, двум бесконечностям - как если бы у бесконечности было два этажа: складки материи и сгибы в душе» ${ }^{8}$. Эта биполярность (материя внизу, а душа вверху, возвышенное и низменное, верхний и нижний этажи космического дома) и микро/макроперцепции как репрезентанты мира принимают, по мысли философа, разные формы в виде драпировок и складок, означающих внутреннюю энергию мира, наполненную монадами и живыми душами. Такое понимание мира, по мысли Делёза, характерно для итальянского маньеризма второй половины XVI века, когда Космос понимался как пластичная материя с переходами, волнами и складками. Ещё одна важная формулировка Делёза, на наш взгляд,это установка связи между такими константами, как складка, время и память в эссе «Фуко». Подчёркивая тесную связь таких страт бытия, как прошлое и настоящее, философ актуализирует мысль Фуко о присутствии внутреннего во внешнем путём разглаживания складок бытия и определения времени как абсолютной памяти. И если у Мерло-Понти складка — это «узорные переплетения», или «промежуточные состояния», то у Фуко это «взаимопереплетение» и «взаимоперекрещивание» в соответствии с платоновской моделью «ткачества»: «Это переплетение напоминает схватку, битву между двумя непримиримыми противниками, между двумя формами бытия-знания. Если угодно, это тоже интенциональность, но обратного действия и разведённая по двум направлениям: она становится исчезающе малой или микроскопической. Это даже не складка бытия, а переплетение двух его

ствия и подчинил себе христианское сознание вплоть до наших дней. Только такой независимый ум, как Рембрандт, мог позволить себе иногда отрываться от традиции и обращаться к духу Библии и к мировоззрению, господствовавшему в христианском искусстве тот недолгий период, когда языческий образ Победы переживал упадок и ещё не возродился в христианское обличье вестника Божьего» // Заксль Ф. Константы и вариации // Мир образов. Образы мира. Антология исследований визуальной культуры.- СПб.; М.: Новое издательство, 2018.- С. 93.

8. Делёз Ж. Складка. Лейбниц и барокко.-М.: Логос, 1998. - С. 7. 
форм» ${ }^{9}$. Внешнее как опыт переживания внутреннего, складка как мыслительный процесс и свойство материи, сгибы души и её саморазвитие суть метафизическое обозначение складки, которое, по мысли испанской исследовательницы Кармен Видаль, определяет символизм материального и духовного пространства 80-х годов XX века и его барочный характер ${ }^{10}$. В этом контексте нам представляется закономерным рассматривать драпировки Бурганова как разновидность складывания, разлома и трансформации, как некую чувственную линию сгиба и трансфер в инореальность, что моделирует особую лёгкость пластики и подвижность образов его скульптурных работ.

В работах «Клетка» (1988), «Клетка» (2015), «Крик» (2000), «Памятник Маркизу де Саду» (1987), «Душа» (1997), «Венера космоса» (2015) возникает птичья клетка, которая символизирует несвободу человека и его души. Это очень важная для скульптора коннотация, которая знаменует ситуацию социальных ограничений, табу и подавления личностного начала. Александр Николаевич так комментировал этот символ: «Да, клетка есть клетка. Это составная часть нашей жизни. Не замечать её было бы неправдой. Для меня это есть и оболочка тела, внутри которого заключена душа, не имеющая предметного обозначения. Клетка - это предмет, из которого вылетают или внутри которого остаются навсегда. И потому, как формула нашего бытия, она есть составная часть нашей азбуки для обозначения жизни. Её прутья составляют прекрасный наглядный контраст в руках скульптора для того, чтобы объяснить этот мир» ${ }^{11}$.

Можно со всей определённостью сказать, что Бурганов репрезентирует персональную историю, используя пластические возможности скульптуры. Диалог художника с публикой посредством символически-абстрактных знаков начинает моделировать новые формы художественной материи и влиять на человеческую упорядоченность мира. Художественная практика Бурганова воссоздаёт пространство другой реальности - зазеркалья повседневного существования. Алхимия скульптора такова, что зритель погружается в пространство духовных миров, постигает скульптурную пластику и её выразительность с помощью языка иносказаний и символов. Наблюдатель устанавливает внутреннюю суть вещей, скрытые концептуальные импульсы, старается обнаружить духовное в материальном. Установка Василия Кандинского на синестетическое видение и постижение внутренних свойств предметов и форм, живущих в ментальном плане, несомненно близка автору скульптуры «Клетка»: «Мир звучит. Он есть Космос духовно действующих

9. Делёз Ж. Фуко.—- М.: Издательство гуманитарной литературы, 1998. Сетевой ресурс. URL: https://royallib.com/book/delyoz_gil/fuko.html (дата обращения: 08.02.2019).

10. См. об этом подробнее: Видаль М.К. Смерть политики и секса в шоу восьмидесятых // Новая литературная история. Т. 24. № 1.- Шарлоттсвилл, 1993.- С. 183-185.

11. Бурганов А. Н. Улыбка слепых (интервью художника с самим собой) // Дом Бурганова. Пространство культуры.-2010.- № 2.- С. 56. 
существ. Такова мёртвая материя живого Духа» ${ }^{12},-$ писал Кандинский в статье «К вопросу о форме». Бурганов не только переосмысливает природу Вселенной и закономерности человеческого существования, но и делает тайное видимым, апеллируя к эмблематической иконографии.

Важнейшее место в творческом наследии Александра Бурганова занимают скульптуры-жестыл. Им художник придаёт важное значение, поскольку язык невербальной семиотики ещё с античных времён играл значительную роль в толковании системы образности (иконография) и скрытых смыслов (иконология) картины. Недавно была переведена и опубликована в России книга известного исследователя Морриса Десмонда «Язык тела. Позы и жесты в искусстве» ${ }^{13}$, в которой автор в увлекательной манере рассказывает о кинетике в шедеврах мирового искусства. Объясняя важные знаки жестовой артикуляции в искусстве, исследователь устанавливает канонические невербальные паттерны, репрезентируемые художниками на протяжении всей истории изобразительного искусства. Для Бурганова самой главной визуальной идеограммой становится рука. Вот как он сам об этом пишет: «Рука - это лицо Бога.

Рука Бога не имеет ни индивидуальности, ни психологии, ни сходства с отдельньмм человеком.

Это не изображение фрагмента тела.

Это - знак судьбыл.

При помощи протянутой руки Бог видит и слущает нас.

Бог есть Бог.

Но с другой сторонь, рука - это символ нас самих.

Это лицо нашей души и наших проблем.

Рука Бога и наша рука обращены друг к другу.

Мыл ждём, чтоб наши пальцыь встретились.

Мы просим о спасении.

Мы просим простить нас.

Мы просим вернуть нам рай и бессмертие, из которого когда-то нас изгнали.

Это наша мечта, наша молитва, наша надежда.

Поэтому, если сказать кратко, руки в моём творчестве - это мои молитвы» ${ }^{14}$.

Рука Творца - устойчивый знак-символ, который повторяется у скульптора в разных вариациях. Он страстно обращается с этим художественным медиумом и предлагает зрителям разные формы его дешифровки: жест-мольба, жест-крик, жест указующий и благословляющий, показывающий движение вверх и т.д. Эти

12. Кандинский В. К вопросу о форме // Кандинский В. Избранные труды по теории искусства. Т. 1.—М.: Гилея, 2001.- С. 225.

13. Десмонд М. Язык тела. Позы и жесты в искусстве.- М.: Ад Маргинем, 2019.

14. Образ руки в творчестве Александра Николаевича Бурганова. Сетевой ресурc. URL: http:// burganov.ru/virtualnaja-vystavka (дата обращения 08.02.2020). 
артефакты призваны усилить эмпатическое сопереживание наблюдателя и на основании оставленных следов реконструировать механизмы визуальных стимулов.

Важной особенностью этих скульптурных композиций является риторический посыл или скрытый вербальный подтекст. Авторская парадигма образа развивается на пересечении визуального и вербального контекстов, хотя слово как таковое отсутствует, но дискурс нарратива очевиден. Изображения Бурганова насыщены метафизической и дидактической риторикой, лингвистическими кодами и особой формой смыслопорождения, когда позиционируется репрезентация смешанного типа, свойственная искусству модернизма. Он фокусирует своё внимание на фрейме $^{15}$, внутри которого формируются индивидуальные и общекультурные смыслы. Мы подразумеваем прежде всего смысловые рамки и устойчивые интерпретационные схемы, которые позволяют скульптору создать визуальную среду, предельно насыщенную кодами и условными знаками. Бурганов предлагает зрителю подобие визуального театра, в котором образ как знак-символ и лингвистическая реальность путешествуют в пространстве и времени, при этом делается акцент на концептуальной и внутренней усложненности репрезентации. Художник стремится побудить зрителя к неспешной и вдумчивой рефлексии, к созерцанию новой антропологии визуальности и грамматики жестов в скульптуре, в континууме которой границы между субъектом и объектом легко преодолеваются.

\section{БИБЛИОГРАФИЯ}

1. Бурганов А.Н. Улыбка слепых (интервью художника с самим собой) // Дом Бурганова. Пространство культуры.-2010.- № 2 .

2. Видаль М.К. Смерть политики и секса в шоу восьмидесятых // Новая литературная история. Т. 24, № 1.- Шарлоттсвилл, 1993.

3. Вотчель К. Сюрреализм в скульптуре. Александр Бурганов. Альманах “Artifex.ru”. Ceтевой ресурс. URL: https://artifex.ru/\%D1\%81\%D0\%BA\%D1\%83\%D0\%BB $\% \mathrm{D} 1 \% 8 \mathrm{C} \%$ D0\%BF\%D1\%82\%D1\%83\%D1\%80\%D0\%B0/\%D0\%B0\%D0\%BB\%D0\%B5\%D0\%BA $\% \mathrm{D} 1 \% 81 \% \mathrm{D} 0 \% \mathrm{~B} 0 \% \mathrm{D} 0 \% \mathrm{BD} \% \mathrm{D} 0 \% \mathrm{~B} 4 \% \mathrm{D} 1 \% 80-\% \mathrm{D} 0 \% \mathrm{~B} 1 \% \mathrm{D} 1 \% 83 \% \mathrm{D} 1 \% 80 \% \mathrm{D} 0 \% \mathrm{~B} 3$ $\% \mathrm{D} 0 \% \mathrm{~B} 0 \% \mathrm{D} 0 \% \mathrm{BD} \% \mathrm{D} 0 \% \mathrm{BE} \% \mathrm{D} 0 \% \mathrm{~B} 2$.

4. Данто А. Сны наяву // Данто А. Что такое искусство? - М.: Ад Маргинем Пресс, 2018.

5. Делёз Ж. Складка. Лейбниц и барокко.- М.: Логос, 1998.

6. Делёз Ж. Фуко.- М.: Издательство гуманитарной литературы, 1998. Сетевой ресурс. URL: https://royallib.com/book/delyoz_gil/fuko.html

7. Десмонд М. Язык тела. Позы и жесты в искусстве.- М.: Ад Маргинем, 2019.

8. Заксль Ф. Константы и вариации // Мир образов. Образы мира. Антология исследований визуальной культуры.- СПб.; М.: Новое издательство, 2018.

9. Кандинский В. К вопросу о форме // Кандинский В. Избранные труды по теории искусства. Т. 1.- М.: Гилея, 2001.

10. Кларк К. Нагота в искусстве. Исследование идеальной формы / Пер. М.В. Куренной и др.- СПб.: Азбука-классика, 2004.

11. Образ руки в творчестве Александра Николаевича Бурганова. Сетевой ресурс. URL: http://burganov.ru/virtualnaja-vystavka/

12. Goffman E. Frame analysis: An Essay on Organization of Experience. Cambridge, 1974

15. См. подробнее об этом: Goffman E. Frame analysis: An Essay on Organization of Experience.Cambridge, 1974. 
13. Cyclades Art. Сетевой pecypc. URL: https://donsmaps.com/cyclades.html

14. Hvattum, M., 2019. Style: "Notes on the Transformation of a Concept", Architectural Histories, no. 7(1), p.22. DOI: http://doi.org/10.5334/ah.367

15. Warner, E.S. 2017. "Marketing the Monumental: Wall Painting at Midcentury," Archives of American Art Journal, vol. 56, no. 2 pp. 26-49. DOI: https://doi.org/10.1086/695628

16. Zuromskis, C. 2018. "The Social Lives of Archival Photographs," Archives of American Art Journal, vol. 57, no. 1, pp.76-85. DOI: https://doi.org/10.1086/698337 